\title{
Was Paul fully Torah observant according to Acts?
}

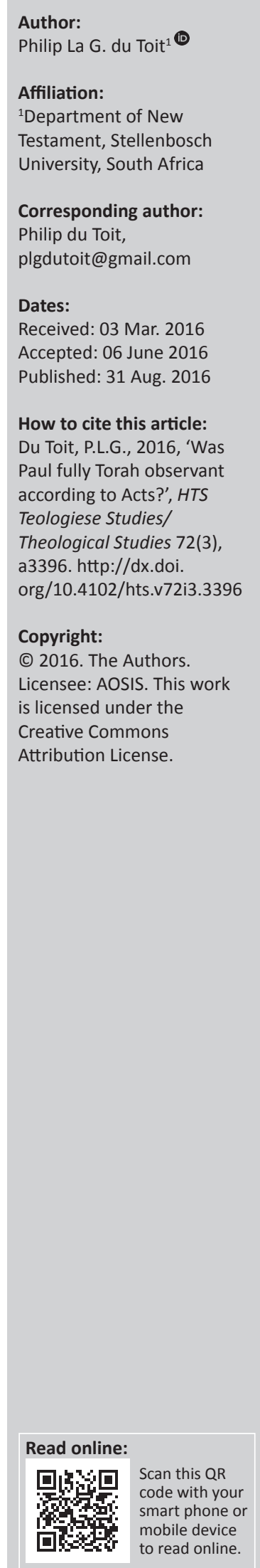

This article primarily examines the question if the Acts of the Apostles portrays Paul as being fully Torah observant. This question secondarily coheres with the question if it can be derived from Acts whether it was expected of all Christ-believers from the loudaioi to fully adhere to the Torah, or that such a belief was universal in the early church. The conclusions on all of these questions are negative. These conclusions are reached by way of analysing these claims against the text of Acts (mainly 15:1-35; 16:3; 18:18; 21:17-26; 21:39; 22:3, 23:6 and 26:5) in comparison with the principle Paul laid out in 1 Corinthians 9:19-23 to be everything to everyone. The latter principle is found to be compatible with the narrative in Acts, although the difference in the approaches of Luke and Paul is acknowledged, especially in terms of their portrayal of the Mosaic Law.

\section{Introduction}

According to the Acts of the Apostles, Paul seems to be loyal to the Torah: in the narrative he agrees to impose ritual requirements on Gentile Christ-believers (15:22-35); he circumcises Timothy, who had a Gentile father (16:3); in Jerusalem's temple he participates in purification rites akin to the way of life of the Ioudaioi (18:18; 21:17-26); he refers to himself as an Ioudaios (21:39; $22: 3)^{1}$ and even a Pharisee $(23: 6 ; 26: 5)$. In the past, these were often set against Paul's urge not to impose ritual restrictions on one another (1 Cor 8-10; cf. Col 2), his view that circumcision severs one from Christ (Gl 5:2-4), his perception of his Pharisaic background as refuse and something to be discarded (Phlp 3:5-8), and his frequent proclamation that believers in Christ are no longer 'under the Law' (Rm 2:12; 3:19; 16:14-15; 7:23; 1 Cor 9:20-21; Gl 3:23; 4:4-5, 21; 5:18; cf. Carson \& Moo 2005:293-294).

In recent scholarship, the perception of the picture that Acts paints of Paul has been varied. Much of this perception results from trying to reconcile the historical data in the Pauline material with that of Acts. For Lentz (1993:171) the portrait of Paul Luke creates is 'too good to be true', especially in terms of his high social status and moral virtue. Following Schüssler-Fiorenza (1976:1), Lentz (1993:171-172) argues that the early Christian movement and its literature attempted to attract and convince persons of the Hellenistic world that Christianity could no longer be perceived as the faith of the uneducated masses, be they Christian, belonging to the Ioudaioi or pagan. In terms of Paul's position to the Torah, Haenchen (1966:265) argued that 'Luke was no longer able to grasp theologically, as Paul had, the legitimacy of the mission to the Gentiles free of the Torah'. Yet Porter ([1999] 2008:190-193) argues that the New Perspective on Paul (NPP), which perceives Paul in stronger continuity with the faith and the way of life of the Ioudaioi, would eliminate this supposed conflict in Acts and Paul's perception of the Law (cf. Franklin 1994; Keener 2012:252-253).

Although many proponents of the NPP understand Paul's identity in Christ as a new identity transcending the identity of an Ioudaios in some way (e.g. Sanders 1983:173, 178-179, 207; Sechrest 2009; Wright 2013:1443-1449), more radical proponents of the NPP argue that Paul remained a fully Law-abiding Ioudaios (e.g. Campbell 2008, 89-93; Eisenbaum 2009, 252; Nanos 2009:4, 2012:123-124; Tucker 2011, 62-114), which, in turn, would bridge the gap between the (alleged) different pictures of Paul in Acts and the Pauline material itself. Much of the latter approach involves relying on the picture of Paul in Acts and in reinterpreting the Pauline material according to the (radical) NPP.

The aim of this article is not to argue from the Pauline corpus whether Paul remained within the identity of the Ioudaioi and thus if he remained to be fully Torah observant. Because I have argued elsewhere from the Pauline material, in dialogue with the NPP and its radical variants, that Paul was not fully Torah observant (including circumcision and dietary laws) and did take on a new identity in Christ (Du Toit 2013a:66, 180; 2015), I work from such a point of departure in approaching the Acts of the Apostles. The main question that this article addresses is thus whether 
Luke's view of Paul is compatible with a view that Paul was not fully Torah observant. In determining whether the Paul of Acts has to be understood as fully Torah observant, the focus will be on the following passages in Acts: 15:1-35; 16:3; 18:18; $21: 17-26 ; 21: 39 ; 22: 3,23: 6$ and 26:5. Yet the latter question coheres with the question whether it was expected of all of the early Christ-believers from the Ioudaioi to fully adhere to the Torah, constituting a secondary focus of this article.

\section{Requirements for Gentile believers (15:1-35)}

Although much has been written on the Antioch incident (G1 2:11-16) and its (possible) relationship with Acts 15, the intention is not to take up this relationship afresh, but to ask two main questions about Acts 15: (1) Would there be a Pauline theological basis and enough reason to believe that he would have agreed to the Apostolic Decree? and (2) did the requirements laid down in the Apostolic Decree constitute an ongoing principle in the early church that differentiated between believers from the Ioudaioi and the Gentile believers in such a way that it was expected of all believers from the Ioudaioi to adhere to the full Torah, including circumcision and dietary laws, in distinction from Gentile believers who only had to adhere to certain restrictions?

According to Acts 15, the initial reason for the quarrel between Paul and Barnabas against those from Judaea, probably false brothers (Bruce 1990:332; cf. Gl 2:4), was that these men from Judaea wanted Gentile Christ-believers to be circumcised in order to be saved (vv. 1-2). On their arrival in Jerusalem, Paul and Barnabas were met by a similar opinion by believers from the party of the Pharisees, but with the added condition that Gentiles should adhere to the whole Mosaic Law (v. 5). Peter, a believer from the Ioudaioi, stood up and explained that God decided to include the Gentiles in the gospel (v. 7) and to give the Holy Spirit to them 'just as to us'

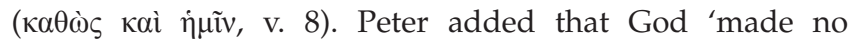

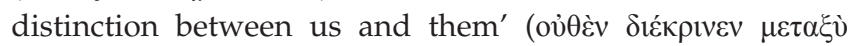

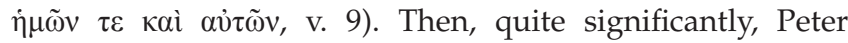
protested against placing a yoke (the Mosaic Law) on the neck of the disciples that neither the patriarchs nor they, Christ-believers from the Ioudaioi, were able to bear (v. 10). Peter then contrasts the Law to the grace in Christ and applies it to believers from the Ioudaioi like himself; a grace that he considers as applicable to them in the same way as to Gentile believers (v. 11). Barrett (1998:xxxvii-xxxviii) considers Peter's mention about the burden of the Law as a point of tension in the book of Acts in light of the rest of the book. Pervo (2009:374) goes further and views verses 9-11 as (Deutero-) Pauline theology that can hardly be ascribed to Peter, implying scepticism about its historicity (esp. v. 10; cf. Eph 2:5-8; Barrett 1998:718-720; Conzelmann 1987:117). ${ }^{2}$ Two elements thus stand out in Luke's account of Peter's speech: (1) there is no distinction between the way in which Gentile believers and believers from the Ioudaioi received the Spirit

2.Although Barrett (1998:718-720) is not as explicitly sceptical about the historicity of the account of Peter's speech as Pervo (see above), he also considers the description of Peter as Paulinist and as making Peter speak more or less like Paul. and the cleansing of their hearts by faith and (2) in terms of salvation, the grace in Christ is contrasted to the Mosaic Law for both Gentile believers and believers from the Ioudaioi. ${ }^{3}$ These characteristics correspond with Peter's words to Cornelius about God showing no partiality and His acceptance of anyone who fears Him (10:34-35; cf. also Paul's speech in 13:39, 43).

There is however no compelling reason to think that Peter's speech is not authentic (Witherington 1998:454). For Peter may have used at the council the argument for freedom which Paul had impressed upon him at the Antioch incident (Gl 2; Fernando 1998:416; Ramsay 1925:162; cf. Longenecker 1981:445). ${ }^{4}$ Paul himself suggests that various matters at the heart of his gospel were part of a shared early Christian tradition (1 Cor 15:11, Bruce 1990:337; Witherington 1998:454). There is thus no compelling reason to think that Peter wanted to proselytise believers as those from the party of the Pharisees (v. 5) wanted to do. Galatians 2:11-14 rather suggests that Peter both lived like and ate with Gentiles, and only withdrew from the latter under pressure from those with a proselytising agenda (Witherington 1998:455).

Furthermore, the remark about the yoke of the Law (v. 10) might seem surprising on the lips of Peter, for the bearing of the yoke of the Law was seen by many as a privilege and a help, and no reason for complaint (Haenchen 1971:446; e.g. Ps 119:97-98). But a few factors have to be considered in terms of the context behind such a reference in Acts: (1) As a Galilean fisherman, Peter might have seen at least parts of the Law as a considerable burden, especially the feasts that would require pilgrimage up to Jerusalem and involve the abandoning of work and family, (2) the attempts to extend various priestly requirements of the Law to all Ioudaioi by the Pharisees and the Qumranites may have led to such a view under the ordinary working class and (3) Jesus seems to have suggested that the yoke of the Law was heavy (Mt 11:30; Sir 51:26; Witherington 1998:454; cf. Bruce 1990:337 on point 1). Dunn (2006:430) goes so far as stating that Peter was 'the bridge-man... who did more than any other to hold together the diversity of first-century Christianity'. ${ }^{5}$ Furthermore, if the Mosaic Law would only have positive connotations for all believers from the Ioudaioi, why would the Mosaic requirements (see below) be considered as a limited set of

3.It could be pointed out that salvation by faith could also be seen as inherently in tension with the idea that continuing adherence to the whole Torah is needed for certain believers in Christ. For the notion that doing the Law leads to 'life' (Lv 18:5) seems to be quoted by Paul in the context of being part of the requirements of the Old Covenant to obtain eternal life ( $\mathrm{Rm} \mathrm{10:5;} \mathrm{Gl} 3: 12)$. It is noteworthy that in text such as Dt 4:1; Ezk 20:11, 13, 21 and Neh 9:29, the same principle of Lv 18:5 is repeated in the context of obtaining eternal life (Sailhamer 1992:346; cf. CD III 15-16; 4Q266, 11 I-II, 12; Pss. Sol. 14:1-5), making it likely that Paul also attached similar connotations to Lv 18:5. The doing of the Law in the context of the Old Covenant thus involved more than merely marking off identity (cf. Moo 1996:648, 2013:209-210; Schreiner [1998] 2013:601-604; cf. Schreiner 2010). It is thus unlikely that the notion of obtaining life by doing the Law would never have existed or just suddenly disappeared with these believers from the loudaioi, even if such a notion merely formed part of their perception about the significance of doing the Law or existed with some of the believers from the loudaioi.

4.This is applicable whether $\mathrm{Gl} 2$ is seen as corresponding with Acts 11:30 (e.g., Bruce 1990:330-331; Marshall 1980:244-247; Witherington 1998: 440-442) or with Acts 15 (e.g., Fitzmyer 1998:539-540; Jervell 1998:404; Polhill 1992:358-359).

5.Cf. how Dunn (2006:430) perceives Peter as serving a kind of mediatory function between the extremes in the early church, being sensitive to both the heritage of the loudaioi, which Paul seemed to have lacked, and an openness to the demands of developing Christianity, which James seemed to have lacked. 
requirements 'not to trouble' ( $\mu$ ì $\pi \alpha \rho \varepsilon v o \chi \lambda \varepsilon \varepsilon \tau v, ~ v . ~ 19) ~ G e n t i l e$ believers and as imposing 'no further burden' $(\mu \eta \delta \dot{\varepsilon} v$

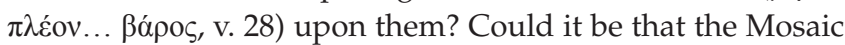
Law was considered by many of the believers from the Ioudaioi as burdensome all together?

The question is thus, was it generally expected of all believers from the Ioudaioi in the early church to adhere to the whole Torah, including circumcision and dietary laws, or was it just a matter of preference for many among them? Did all believers from the Ioudaioi think this way? It is only reasonable to suspect that those from Judaea who wanted Gentile believers to be circumcised (vv. 1-2) and those believers from the party of the Pharisees who wanted Gentile believers to adhere to the whole Mosaic Law (v. 5), would also propagate full Torah observance for themselves. But it is another question if that means that there was consensus among early Christ-believers from the Ioudaioi that it was expected of all of them to adhere to the full observance of the Torah.

Although it is quite evident from the text of Acts 15 that the motivation of those from Judaea and the believers from the party of the Pharisees was that circumcision and full Torah observance had to complement salvation (vv. 1, 11), and that Peter's reaction indicated that there was freedom from the Law for Gentile believers and believers from the Ioudaioi in respect of salvation, it may be asked if the freedom from the Law did not go beyond salvation for all believers. Strictly speaking, we have no indication from Acts that all believers from the Ioudaioi thought that circumcision or full observance of the Law was expected of all believers from the Ioudaioi. That the latter assumption might have been 'prevailing' (Woods 2015:115) for many believers for the Ioudaioi is certainly possible, but if so, that would not mean that such an assumption would have been universal for all believers from the Ioudaioi. It is in fact quite possible that Luke meant to say that the believers

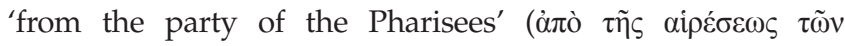

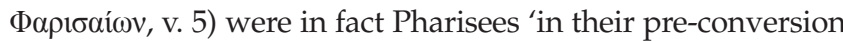
days', just like Paul, and that their 'old attitudes' were carried over to their belief in Christ (Marshall 1980:249).

Although the Apostolic Decree (vv. 20, 29) on a surface level seems to accommodate believing Gentiles ${ }^{6}$ among believers from the Ioudaioi in order that they could have mutual fellowship (cf. Talbert 2005:135; Parsons 2008:220), it may be asked if those who were really being accommodated were

\footnotetext{
6.As argued in some length elsewhere (Du Toit 2013b), the idea that these .As argued in some length elsewhere (Du Toit 2013b), the 'idea that these requirements represented an earlier form of the seven "Noahide Laws' (e.g., Campbell 2008:6; Eisenbaum 2009:252; Nanos 1996:50-56; Tomson 1990:50),
a belief in (later) Rabbinic Judaism that implies that 'righteous Gentiles' who adhere a belief in (later) Rabbinic Judaism that implies that 'righteous Gentiles' who adhere
to these seven laws (prohibitions on idolatry, blasphemy, murder, theft, sexual
immorality, eating living flesh, and exhortations for the establishment of courts of immorality, eating living flesh, and exhortations for the establishment of courts of justice) would have a place in the world to come, is unfounded. The prohibitions listed in Ac 15:19-32; $16: 1-5$ and $21: 25$ do not correspond well with the seven Noahide Laws and is rather to be interpreted as having a Mosaic origin, constituting a practical arrangement in the early church with the intention to establish unity. That the idea behind the Noahide Laws is present in the book of Jubilees 7:20-21 is doubtful (the restrictions in Jubilees do not correspond well with the seven Noahide Laws; the requirement that the laws would be binding on all people is absent: that Laws; the requirement the those concerned would be 'righteous Gentiles' is absent; that they would obtain place in the world to come is absent). That the Noahide Laws existed in some kind of early form in the Didache $(3: 1-6 ; 6: 3)$ is questionable too. Apart from the tendency to date it later than Paul, the Didache lacks a reference to Noah, and the correspondences that there are with some of the stipulations in the Didache with the Noahide Laws are embedded within many other commands and covenantal requirements akin to the Mosaic Law.
}

not the more Torah-orientated believers from the Ioudaioi. If one compares the situation in Acts 15 with the situation addressed in Romans 14, it is noteworthy that the 'weak' persons in Romans 14:1, 2 and 15:1 are portrayed as believers from the Ioudaioi who adhered to dietary restrictions and the observance of days out of continuing loyalty to the Mosaic Law (Moo 1996:829; Schreiner [1998] 2013:770). ${ }^{7}$ It seems that they condemned Gentile believers who did not adhere to these restrictions ( $\mathrm{Rm} \mathrm{14:3).} \mathrm{The} \mathrm{'strong'} \mathrm{with} \mathrm{whom} \mathrm{Paul}$ agrees (Rm 14:14a, 20; 15:1) would then be Gentile believers who believed that the coming of Christ has brought an end to the ritual requirements of the Mosaic Law (Moo 1996:831; cf. Cranfield 1979:697).

Although the things listed in the Apostolic Degree (Ac 15:20, 29) mostly cohere with Mosaic, ritual requirements of the Old Testament (Lv 17:10-14; 19:26; 1 Cor 8:1,4-13), porneia seems to carry a stronger ethical connotation. Yet, although porneia might have been intended in a mainly ritual sense of sexual activities that defile a person (cf. Polhill 1992:367), it probably stands in direct connection with the sexual immorality associated with pagan religious festivals (cf. 1 Cor 10:7-8, Gaertner 1993; Witherington 1998:466). Notwithstanding, even if the reference to porneia might have involved an ethical reprimand to Gentile believers, on a deeper level, the other conditions in the Decree could well be a compromise to accommodate 'weak' ${ }^{8}$ believers from the Ioudaioi (cf. Bruce 1990:331; Fernando 1998:425) and not so much a requirement for Gentile membership (contra Polhill 1992:366). From the text of Acts it is thus not clear whether the whole of the Jerusalem church was zealous for the Law. It is quite likely that there was a strict Law-abiding group within the Jerusalem church (Longenecker 2015:196).

Paul's reaction on the Apostolic Decree is not known from the text of Acts 15, and is neither clear from his own letters. ${ }^{9}$ Yet there is no reason to suspect that he would disagree with it either (cf. Bock 2007:643). Using Paul as a guide, Bock (2007:644) suggests two options: '(1) keep the law scrupulously for the sake of evangelizing Jews, or (2) be less scrupulous for the sake of Gentiles (1 Cor. 9:19-22; Rom. 14-15). Each person is to do what conscience permits without imposing a requirement on someone who has different convictions'. In other words, Paul might have

7.Several factors are in favour of this interpretation: (1) The differences between the Ioudaioi and the Gentiles is an important theme in Romans (e.g., Rm 1:14-16; 9:24; 10:12; 15:8-13). The significance of the OT food laws was a primary issue in early believing communities (e.g., Mk 7:19b; Ac 10; 15; Gl 2:11-15). (2) Paul's plea for understanding and acceptance of the 'weak' makes it clear that they were no propagating a view antithetical to the gospel. (3) Paul's failure to mention 'food sacrificed to idols' (cf. 1 Cor 8:1), his reference to the observance of special days and abstention from wine make it unlikely that the dispute in Romans can be confined to food offered to idols. (4) The practices that Paul ascribes to the 'weak' can all be related to requirements in the Mosaic Law (Moo 1996:829-839). See also Gagnon (2000) who argues against Nanos (1996:105) who contends that the 'weak' refers to those of monotheistic 'Jewish' faith. Gagnon shows from the context that the 'weak' persons have to be believers in Christ.

8.In this regard Longenecker (2015:207) points out that Paul's reference to the 'pillars' (the elder apostles) in GI 2.9 could imply that in some ways Paul considered them as weak. Paul does not directly speak of them as pillars, but writes that they 'were

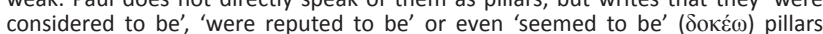

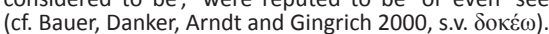

9.Some argue that the Apostolic Decree is implied behind 1 Cor 5-10: sexual immorality in 5-7 and food sacrificed to idols in 8-10 (Bruce 1990:331. Carson \& Moo 2005:294-295; Polhill 1992:371-372). But if so, these do not cover all the requirements of the Decree. 
adhered to the Decree, especially the ritual requirements, for the sake of those with a 'weak' conscience (cf. Bruce 1990:331; Longenecker 2015:230).

\section{Timothy's circumcision (16:3)}

Could Paul's circumcision of Timothy (Ac 16:3) serve as evidence that Paul personally adhered to circumcision or promoted circumcision for believers from the Ioudaioi, including himself? The text specifically points out that Paul

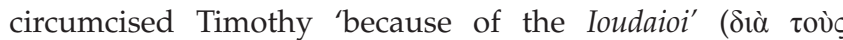

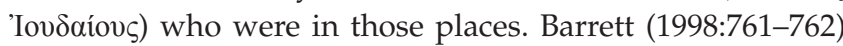
rightly points out that the fact that Timothy had a Greek father (his mother's identity is not mentioned), makes Timothy's circumcision somewhat problematic. Why would Paul want to present Timothy as a believer from the Ioudaioi rather than a Gentile believer, as with Titus who remained uncircumcised (G1 2:3)? Although Barrett (1998:761) is right that Gentiles were admitted in synagogues, the kind of sentiment around the admittance of Gentiles in the temple by some, as reported in Acts 21:28 and 24:6, is probably the main reason why Paul would want to present Timothy as a believer from the Ioudaioi rather than a Gentile believer.

Rather than Paul circumcising Timothy in order for him to become part of God's messianic people, the most natural interpretation is that Paul circumcised Timothy 'to accommodate Jewish sensitivities after the principle of salvation by grace through faith has been established (15: 11)... This, then, is an act of accommodation, part of Paul's missionary strategy (cf. 1 Cor 9:20)' (Talbert 2005:137; cf. Carson \& Moo 2005:295; Parsons 2008:219; Schnabel 2012:665). Paul's action was thus consistent with the principle that he laid down in 1 Corinthians 9:20 to become 'as' or 'like' $(\dot{\omega} \varsigma)$ an Ioudaios to the Ioudaioi in order to win them over for Christ (see below). Circumcision itself was therefore ethically indifferent for Paul (Bruce 1990:59; Longenecker 2015:204; cf. 1 Cor 7:19; Gal 5:6, 6:15). The fact that Timothy had a Greek father, and that Paul theoretically could have presented him as a Gentile believer, thus serves to show that Timothy's circumcision cannot be used as proof that Paul promoted circumcision for believers from the Ioudaioi.

\section{Paul's participation in purification rites (18:18; 21:17-26) and 1 Corinthians 9:19-23}

The next argument that is normally advanced in support of the idea that Paul was still fully Torah observant, according to Acts, is the reports of his participation in purification rites. It is noteworthy that both Paul's ritual acts, as reported in Acts, are set within a polemical context. According to 18:12-13, the Ioudaioi made a united attack on Paul in bringing him before the tribunal. They alleged: 'This man is persuading people to worship God in ways that are contrary to the law' (NRSV). Yet, after a favourable decision from Gallio, and the Ioudaioi being averted, Paul decided to stay in Corinth, and just before leaving, it is narrated that he had his hair cut, for he was under a vow (v. 18). Which vow is referred to?
Although it is possible that it refers to a Nazirite vow (Jervell 1998:465-466; Parsons 2008:261), ${ }_{1}^{10}$ it probably refers back to Paul's nightly vision from the Lord where he encouraged Paul to go on speaking and not be silent, and that he would protect Paul from harm. The cutting of his hair would then not be to obtain certain blessings from God, but it would be a 'private religious exercise' (Bruce 1990:398) wherein Paul would show his thankfulness to God who enabled him to complete his mission in Corinth under God's protection (ibid; Bock 2007:764; Witherington 1998:557). ${ }^{11}$ Yet it is not impossible that the shaving of Paul's head might have involved some kind of delayed reaction to pacify the earlier antagonism he experienced from the Ioudaioi and their allegations about Paul not adhering to the Law (vv. 12-13).

According to Acts 21, after Paul's arrival in Jerusalem, he was confronted by the elders who told him that thousands among the Ioudaioi came to belief (in Christ) and that 'all' ( $\pi \tilde{\alpha} \varsigma$ ) of them were zealous for the Law (v. 20). This is probably a hyperbole to indicate a significant response (Bock 2007:841; Witherington 1998:647). But even if it is meant literally, the many being zealous for the Law does not necessarily imply that all believers from the Ioudaioi in the early church were zealous for the Law. It is in fact likely that many of Paul's converts from the Ioudaioi, when they joined communities of largely Gentile believers, might have ceased to be Torah observant. Teachings such are found in Romans 2:25-30, Galatians 4:9 and 5:9 seem to point in this direction (Witherington 1998:648). Note especially the first person plural ('we') in which Paul states that believers in Christ, including himself and believers from the Ioudaioi by implication, are not under the Law or the curse of the Law any more (Rm 6:15; 7:5-6; Gl 3:13, 23-25; 4:2, 4, 5; 5:1, 5). In 1 Corinthians 9:20 Paul states specifically that he is not himself under the Mosaic Law (see below). In terms of food restrictions and Sabbath, Paul states in Romans 14 that nothing is unclean in itself (v. 14) and that Sabbath laws are no longer compulsory for believers (vv. 5-6), which hardly indicates that he still observed these laws (Dunn 1988:811;2015). As Esler (1987:128) notes, Acts 16:15, 34 and 18:7 are probably indicators within Acts that Paul renounced Levitical food laws.

In the narrative in Acts 21, the elders reported to Paul that they were told that he taught all the Ioudaioi living among Gentiles to forsake Moses, not to circumcise their children or to observe the customs (v. 21). Paul was then told to go through purification with four men that were under a vow ${ }^{12}$ and pay for the shaving of their heads, because these believers who were zealous for the Law would certainly hear that Paul would come (vv. 22-24). In this way, these people would

10. While a Nazirite vow could take place outside of Israel (Parsons 2008:261), it is likely that if Paul would have taken a Nazirite vow, he would have adhered to the

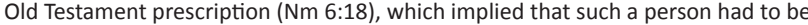
in Israel for at least 30 days before his hair was cut and offered at the temple (Bruce 1990:398; Longenecker 1981:488; Marshall 1980:300)

11.It may be noteworthy that this kind of vow was not unknown in the Greek world (\$4 in Horsley 1981:23-24; §46 in Horsley 1983:72-75; cf. Barrett 1998:877-878).

12. While the four men probably took a Nazirite vow, Paul did not complete his, which required at least 30 days, including reporting to one of the priests and being sprinkled with water of atonement on the third and seventh days (Bruce 1990:446; Fernando 1998:553; Longenecker 1981:520; Witherington 1998:649; cf. M Nazir 3:6). 
know 'that there is nothing in what they have been told about you, but that you yourself observe and guard the law' (NRSV, v. 24b). Paul then adhered to this instruction from the elders (vv. 26-27), but these Ioudaioi from Asia were not convinced, stirring up the crowd and continued their antagonism against Paul by alleging that he taught against the Ioudaioi, their Law, and the temple by bringing Greeks into it (v. 28).

It is a question whether the elders' instruction would represent their deepest conviction about the position of believers from the Ioudaioi toward the Law in that the elders would consider such an action as natural and obvious, or if they proposed an emergency measure to avert Paul's detractors, to keep affirming Paul's mission, and/or to maintain unity in the believing community (cf. Longenecker 1981:520; Schnabel 2012:880). Peterson (2009:587) is probably right that Paul may not have shared the elders' optimism about the effect of the vow (cf. Bruce 1990:447).

Another question is whether there was something true about the allegations against Paul, which were similar to those against Stephen (6:13-14). Why would the crowd not be convinced about Paul's loyalty to the Law when he underwent purification? It is true that Paul did not actively go around to persuade believers from the Ioudaioi to become non-observant of the Law (Marshall 1980:344; Witherington 1998:648), or that he did not consider himself as sinning against the Law, the temple (25:8) or the customs of the fathers (28:17). But nowhere does Paul insist that believers from the Ioudaioi should remain fully Torah observant either (so Witherington 1998:648). The evidence from Paul's letters, rather, seems to point in the other direction. According to Pervo (2009:544), the Law was absolute for Paul, and he did not generally encourage believers from the Ioudaioi to have their sons circumcised, but in fact recommended that believers from the Ioudaioi in mixed churches should not circumcise their sons (Gl 5:3; cf. Calvin) and probably considered those who did so as 'weak' (cf. Barrett 2002:331; Rm 14-15; 1 Cor 8; 10). Note especially the first person plurals in Galatians 5:1 and 5 ('we'), implying that the instruction not to circumcise includes Paul himself and believers from the Ioudaioi by implication. For Barrett (2002:331) Paul taught his fellow Ioudaioi 'to sit loose to legal regulations (e.g. Gal. 2.12-14; 1 Cor. 10.25, 27) and regarded circumcision as an irrelevancy (1 Cor. 7.19)'. The latter notions about Paul's perception of the Law cause Pervo (2009:543-546) to doubt the authenticity of Luke's account of Paul's vow.

But the historicity of Luke's account can be accounted for by pointing to the principle Paul laid down himself in 1 Corinthians 9:19-23 (so Bruce 1990:447; Fernando 1998:553; Gaertner 1993; Marshall 1980:346; Peterson 2009:586; Polhill 1992:512), being like an Ioudaios to the Ioudaioi (v. 20), being like someone without the Law to those without it (v. 21), and becoming like a 'weak' person for the 'weak' (v. 22), in order to save some of them. Paul qualifies his relationship to the Law as not being himself 'under the Law', yet not being 'without the Law of God', but as being 'under the Law of Christ' (v. 21). Paul thus did not see himself as being under the Mosaic system or any other system that might have replaced it, but under 'that which witnesses to Christ in a broader and more comprehensive sense' (Thiselton 2000:704; cf. Fee 1987:430). ${ }^{13}$ But does such an interpretation of the principle laid down in 1 Corinthians 9:19-23 mean that Paul was hypocritical, especially if his conduct in Acts 21:20-26 and Galatians 2:11-14 is compared? Nanos (2012) thinks so. ${ }^{14}$ But as Thiselton (2000:703) argues, Paul's freedom from the Law has to be understood in both directions. Just as Paul did not view it necessary to comply with Mosaic regulations on circumcision, feast days and food, he did not regard it as forbidden for a Christ-believer to undergo something such as the Nazirite vow (or similar) either. Additionally, when the contexts of 1 Corinthians 9:19-23 and Galatians 2:11-14 are compared, the former context differs from the latter in that the 'winning' (salvation) of unbelievers is at stake in the former, whereas Paul addresses believers in the latter. Regarding Paul's confrontation with those in Jerusalem in Acts 21:20-26, Wright (2013:1441) notes that Paul who

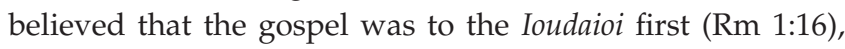
had to choose between either leaving the impression that he is loyal to the Torah or leaving the impression that he tore up Scriptures. Under these difficult, tricky and life-threatening political and/or religious circumstances, Paul chose the former. Paul was actually very consistent in adhering to his own principles:

He could only be charged with hypocrisy and inconsistency if he had acted in opposition to his own principles or had professed to believe these practices essential when he really thought otherwise. (Longenecker 2015:231)

If Paul could be understood to adhere to the principle laid down in 1 Corinthians 9:19-23, Paul's willingness to take a vow as described in Acts 21:17-26 does not need to point to the notion that Paul would have been fully Torah observant (contra Conzelmann 1987:180; Johnson 1992:379; Keener 2012:253). The early church certainly was in a developmental phase in terms of their identity, which included both Gentile believers and believers from the Ioudaioi. The question is not whether there were believers from the Ioudaioi who still wanted to partly define their identity by adhering to the full Torah, especially food laws and circumcision, even though they might have been great in number. The question is rather if one could derive from the text of Acts that a fixed principle has been laid down in the early church that the believers from the Ioudaioi were all expected to distinguish themselves

. authenticity of the vows in Acts by pointing to the forty lashes that Paul received from the loudaioi (2 Cor 11:24). As Roman citizen he could have escaped the from the loudaioi ( 2 Cor $11: 24$ ). As Roman citizen he could have escaped the
synagogue whippings by an appeal to the imperial authorities, but that would synagogue whippings by an appeal to the imperial authorities, but that would
mean that he would sever himself from the fellowship of the synagogue. He was thus willing to endure punishment to keep ties with the synagogue (which was an important venue for his ministry), although he was theologically separate from the core-identity of the loudaioi.

14.This kind of perception on the traditional interpretation of 1 Corinthians 9:19-23, as well as a resistance to the notion that Paul did not see himself as not being under the Torah, has led Nanos (2012) and others in the Radical NPP to question the traditional interpretation of this passage and, on the basis of halakhah, to propose that Gentiles believers existed as a subgroup within the believing community, subjected to a limited set of legal requirements that were different from believers from the loudaio who would have been subjected to full Torah observance (e.g., Tomson 1990:276-277; Tucker 2011:102-107). As argued elsewhere (Du Toit 2015a:32-35),

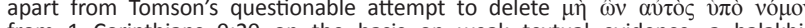
from 1 Corinthians 9:20 on the basis on weak textual evidence, a halakhi interpretation is rather postmodern in nature and implies that Paul did not give up anything, contrary to the notion of Paul's enslavement of himself (1 Cor 9:19). 
from Gentile believers in terms of Torah observance. On these questions the answer has to be negative. Neither can one derive from Paul's vows that he would adhere to such a fixed principle. He was rather like an Ioudaios to the Ioudaioi (1 Cor 9:20), or in this case, to believers from the Ioudaioi who demanded full Torah observance.

How must one then interpret the allegations against Paul of the believers from the Ioudaioi (Ac 21:21) or from other Ioudaioi $(21: 28 ; 24: 6)$, and the reaction of the Ioudaioi from Asia on Paul's vow (21:27-28)? Although Paul probably did not directly prohibit believers from the Ioudaioi to circumcise or actively prevented them from adhering to the customs, such implications were probably implied in Paul's teaching (see above). The same is probably true of the allegations against Stephen's teaching (6:11-14). It is not so much Paul and Stephen's inherent antagonism against the Law in their teaching that aggravated those who wanted to protect the Mosaic Law and preserve the identity of the Ioudaioi, but rather the implications that would arise from the kind of teaching that the Law has been fulfilled and completed in Christ (cf. Rm 7:5-6; 10:4; 2 Cor 3:7-17; Gl 3:10-13, 23-25; 4:4-5, see Du Toit 2013a). Within this line of reasoning, Longenecker (2015) notes that

had it not been for the Jerusalem church's mission to the national customs, he [Paul] would have carried out his message to its logical conclusion and let the old practices of Judaism drop in his own life and in those of his Jewish converts. (p. 204)

In Acts, the latter kind of implication could be derived from Stephen's reference to (1) the Most High who does not dwell in houses made by hands, by pointing to God's cosmic dwelling (7:48-49, implying that the physical temple has become redundant), (2) to the Law, which they received from angels but did not keep (v. 53, implying that the Law could not bring about righteousness and constituted a plight in need of fulfilment) and (3) to the Son of Man standing at God's right hand (v. 55, implying that Jesus has become the new supreme, cosmic authority surpassing Moses' authority; cf. Marshall 1980:130-131; Bruce 1990:189; Longenecker 1981:335-336; Peterson 2009:242-243). In Paul's speech, the fulfilment and completion of the Law may lie behind his reference to (1) those believing, who are freed from everything they could not be freed from by the Law of Moses (13:39, implying that belief in Christ supersedes the power of the Law and accomplishes what the Law could not accomplish, cf. Marshall 1980:228; Polhill 1992:343; Talbert 2005:121), (2) to a new work 'in your days' (v. 41, implying the inauguration of something new). (3) Paul's urge to converts of the Ioudaioi 'to continue in the grace of God' (v. 43) might have implied that the age under the Law culminated in the grace in Christ for all people (cf. Marshall 1980:229; Longenecker 1981:428), requiring one not to revert back to the old age under the Law. Similar sentiments probably lie behind 14:3; 15:11; and especially 20:24 where Paul connects grace to the gospel.

The similar allegations against Stephen (6:11-14) and Paul $(21: 21,28 ; 24: 6)$ thus did contain some truth. Although the allegation that Paul would have defiled the temple by bringing Gentiles into it is most likely untrue (Bruce 1990:449-450; Stott 1990:344), ${ }^{15}$ the other allegations seem to be based on a fundamental misunderstanding of the message(s) that Stephen and Paul preached. For them, their teaching did not denigrate the temple, the people or the Law, but revealed their true glory (Stott 1990:343-344). According to Paul's teaching in Acts, it was precisely in honouring the true teaching of the Law and the Prophets wherein the message of the fulfilment and culmination of Israel's hope laid (13:23-24, 27, 32; 24:14-15; 26:6-8; 28:20, 23): Israel's Messiah died on the cross and was raised from the dead in order to forgive the sins of the world $(13: 38 ; 26: 18)$ and to bring eternal life to all people $(13: 46,48)$, including Israel. Within the ideas of fulfilment and culmination, there always lies the idea of an inauguration of something new and thus a replacement of the old by the new. There is thus both continuity and discontinuity. At the deepest level, the antagonists of Paul (and Stephen) reacted against an element of discontinuity inherent to the gospel itself.

On the one hand, Paul's conduct (i.e. taking a vow) was probably intended to show that he was not against the Torah or against Ioudaioi in principle. His freedom in Christ allowed him to have the liberty to be like an Ioudaios for the Ioudaioi, especially in a polemical context, and to promote thereby the unity of the early church, which was still in the process of appropriating the new found identity in Christ. But on the other hand, his conduct did not necessarily mean that he saw himself as still being under the dispensation of the Mosaic Law. Neither did his conduct imply that he held the conviction that all Christ-believers from the Ioudaioi were obliged to fully adhere to the Torah in distinction from Gentile believers.

Schnabel (2012:879) is thus essentially right that Paul's accommodation (1 Cor 9:19-23) 'is not absolute'. In terms of being an Ioudaios to the Ioudaioi, Paul did not regard the Ioudaioi as the only people where salvation was possible. He did not consider the temple as the central place of worship any more, or believed that he still had to bring sin and guilt offerings. In terms of being a Gentile to the Gentiles, he could not become a full Gentile in the sense of adapting paganism (e.g. to worship in a pagan temples or visit prostitutes). Neither could he become a religious relativist or polytheist. Ultimately, Paul was constrained by Jesus as Israel's Messiah and the Saviour of the world, calling people from the Ioudaioi and Gentiles to a new identity in Christ, making it impossible for him to live as an Ioudaios in every respect (cf. ibid). Paul's accommodation thus mostly revolves around accommodating cultural or religious traditions without forfeiting the core of his gospel or the new identity in Christ.

15.Bruce (1990:449) refers to inscriptions found in 1871 and 1935 that read that no foreigner could enter within the barricade which surrounded the temple and enclosure, and that anyone who was caught doing so should have himself enclosure, and that anyone who was caught doing so should have himself [or herself] to blame for his [or her] death. Even Titus reminded the loudaioi that the Romans had given them 'leave to kill such as go beyond it [the barricade] though he were a Roman' (Josephus, Wars. 6.2.4). It would thus have been absurd that Paul would allow such a thing (ibid:450). It is a question though if Paul would have brought Timothy into the inner court. Having a Gentile father (16:3), it could be that Paul's opponents perceived Timothy as a Gentile and suspected that Pau might have brought Timothy into the inner court of the temple (cf. Wall 2002:297). 


\section{Paul's reference to himself as an loudaios (21:39; 22:3)}

Although many commentators contend that in Paul's reference to himself as an Ioudaios $(21: 39 ; 22: 3)$ he simply saw himself as one (e.g. Barrett 2002:337; Marshall 1980:352; Pervo 2009:553), such a reading may be too simplistic.

After Paul's attempt to complete the purification ritual in the temple was greeted with extreme antagonism (21:26-28), the whole city was stirred up, they grabbed Paul and dragged him out of the temple in order to kill him (vv. 30-32). The tribune then came to his rescue, chained him and tried to get behind the allegations (vv. 33-34). After carrying Paul to the steps because of the violence of the crowd, they shouted that he must be done away with (vv. 35-36). When Paul was given a chance to speak, he immediately started by indicating that he was 'an Ioudaios from Tarsus in Cilicia, a citizen of no obscure city' (v. 39). The circumstances under which Paul responded to the tribune were life-threatening and the context was thus highly polemical. In Paul's identification of his origin and citizenship, Witherington (1998:663) points to the fact that to a great extent people were judged by the importance of the place where they were born. Tarsus was an important and respected city with about 100000 residents of whom only a minority were citizens. Given the circumstances it was probably Paul's only way out.

When Paul subsequently addresses the crowd in Hebrew, repeating his origin and citizenship as Ioudaios from Tarsus in Cilicia, he adds that he was educated at the feet of Gamaliel according to the strict manner of the Law of their fathers, being zealous for God (22:2-3). Paul's reference to being an Ioudaios involves his place of origin, his citizenship and his education. His reference to being an Ioudaios thus has more to do with his former, national identity and his pedigree (cf. Schnabel 2012:899-900) than his current identity in Christ. ${ }^{16}$ The latter notion is strengthened in the light of his retelling of the change that came into his life because of the encounter he had with the risen Christ on the road to Damascus, followed by the new way in which he perceived Stephen's death (by implication) and his receiving of his mission to the Gentiles (vv. 4-21). Paul's reference to being an Ioudaios could thus be another example of Paul being like an Ioudaios for the Ioudaioi, for he aimed to win their favour in order to bring the gospel to them and hoped to change their minds in wanting to kill him. It is noteworthy in this regard that before Festus, Luke narrates that Paul said that he 'in no way committed an offense against the law of the Ioudaioi' (25:8) and that he 'has done no wrong to the Ioudaioi' (25:10), implying that Paul is 'respecting the customs of the Jews, not as a Jew but as a Roman' (Mount 2002:157). Similarly, before Agrippa, Paul is frequently reported to refer to the antagonism from 'the Ioudaioi' (26:2-4, 7, 21; cf. also Paul's general references to 'the Ioudaioi' in 20:21 and 28:19).

16. Paul could refer to his 'kinsmen according to the flesh' (Rm 9:3) which was an aspect of his identity that was on a different level than his spiritual identity (child of his identity that was on a different level than his spiritual identity (childhood) in Christ (Rm 8:16; Gl 4.5). By still being a loudaios in terms of ethnicity did not mean that Paul still adhered to the whole Mosaic Law or that he did not acquire a new core-identity in Christ.

\section{Paul's reference to himself as a Pharisee (23:6; 26:5)}

But what about Paul's reference to being a Pharisee (23:6;26:5)? Within the same chain of events following Paul's arrest and his words to the tribunal and the crowd (21:33-22:29), Paul appeared before the council the next day (22:30). After being struck on the command of the high priest, he noticed that one part of the bystanders were Sadducees and the other Pharisees (23:1-6). This is when Paul cries out to the council, saying: 'I am a Pharisee, a son of Pharisees. It is with respect to the hope and the resurrection of the dead what I am on trial' (ESV, v. 6). The context is again polemical and focused on winning people over for the gospel. By identifying with the Pharisees, Paul tried to divide the crowd on the resurrection, and confirm the validity of the resurrection itself. On one level this seems like a 'clever rhetorical ploy' (Johnson 1992:400). But on another level, the larger aim of Paul's reference to being a Pharisee is to be 'everything to everybody' (1 Cor 9:22) in order to win them over for the gospel (1 Cor 9:23; Bruce 1990:465). Just after the event, Luke reports that the Lord stood by Paul, encouraging him on the basis of Paul's testimony 'to the facts about me in Jerusalem', of which Paul had to testify in Rome as well (v. 11). Parsons (2008:315) is thus right that the point was not that Paul wanted to present himself as a Torah-abiding Pharisee, but that he wanted to redirect the focus to the resurrection of the dead. In other words, Paul's intent in his reference to being a Pharisee was to point out that he was a product of Pharisaic instruction, with specific reference to its view on resurrection (cf. Witherington 1998:691). In a sense, belief in the resurrection of Christ was thus to take the belief in the resurrection of the Pharisees to its full conclusion (cf. Marshall 1980:364; Fernando 1998:567; Talbert 2005:196).

Before Agrippa (26:5), Paul's referral to being a Pharisee in his former life is in aorist indicative form $\left(\varepsilon_{\zeta} \eta \sigma \alpha\right)$, constituting a snapshot in the past (Wallace 1996:555; so Witherington 1998:740; Schnabel 2012:1003). Paul's reference to 'our'

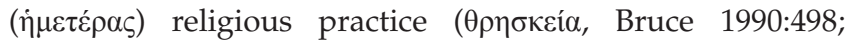
Witherington 1998:740, cf. Col 2:18; Ja 1:26-27; Barrett 1998:1152) does not necessarily point to Paul still perceiving himself as a Pharisee or that Paul 'thoroughly identifies with being Jewish' (Bock 2007:928; cf. Polhill 1992:558), but rather that his belief in Christ shares roots with Pharisaism, especially in terms of resurrection. For Paul makes the motive of his reference to such a notion explicit: 'Why is it thought incredible by any of you that God raises the dead (v. 8)?' Within this specific context, one could thus not derive from Paul's reference to his former life as a Pharisee that he still lived as one (Witherington 1998:740). ${ }^{17}$

\section{Conclusion}

In conclusion, although the Acts of the Apostles seems to portray Paul's relationship with the Torah in a positive light, it

17. As argued elsewhere, Paul's references to himself as an Israelite (Rm 11:1; 2 Co $11: 22$ ) and a Hebrew (2 Cor 11:22) refer more to his pedigree and ethnic heritage than his current identity (2013a:62-64, 289-290). Even his reference to being a Pharisee in Phlp 3:5 refers to his former life as a Pharisee, for in verse 7 Paul refers to such a pedigree (involving other accomplishments and privileges by birth) in the

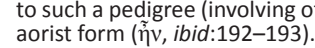


does not have to contradict the notion that Paul saw himself as not being under the Law (1 Cor 9:20). There is no indication in the Pauline material that Paul would have rejected the Apostolic Decree, as it would fit in with Paul's policy of accommodation laid out in 1 Corinthians 9:19-23 to be everything to everyone. The same principle can be applied to the circumcision of Timothy. Paul probably accommodated Ioudaioi who suspected that Paul brought Timothy into the temple. Paul's participation in purification rites can also be understood in this way, especially if the polemical context in which such participation in these rites is considered. Paul's reference to being an Ioudaios by birth identifies his pedigree and national identity rather than his current identity in Christ. Even Paul's reference to being a Pharisee, once in the present tense and once in the past tense, constitutes his doctrinal point of convergence in terms of the resurrection of the dead, rather than his current identity in Christ. Both Paul's references to being an Ioudaios and being a Pharisee occur within highly polemical contexts, which aim to convince his hearers of his intentions and avert his detractors. The principle of being everything to everyone thus applies here too. It can thus not be derived from the text of Acts that Paul was fully Torah observant.

Simultaneously, there is no evidence within the text of Acts that it was expected of all Christ-believers from the Ioudaioi that they should fully adhere to the Torah, or that such a belief was universally held, even though believers from the Ioudaioi thinking like this might have been a majority. The narrative of the situation in the early church regarding Gentile believers and believers from the Ioudaioi, especially in the Apostolic Decree, can be interpreted as an early measure within the church to bring about unity and accommodate everyone. In context, the believers from the Ioudaioi might even be considered as weak, and as those being accommodated.

Lastly, although arguing for compatibility, one has to acknowledge the different aims of Luke and Paul, both in terms of the way in which Paul is portrayed and in terms of the way in which the Law is perceived (cf. Dunn 2006:386). Marguerat (2004:152) is probably right that Luke, in his reference to Israel's rejection of their Messiah (27:16-28), wanted to show the unresolved tension between faith in Christ and the Ioudaioi, and that the break stems from a decision within the Ioudaioi and not from an initiative within the early church. But I am not convinced that Luke wanted to reinforce the consciousness of believers' identity in terms of where the ekklesia came from or that he wanted to restore their relationship to Israel (ibid:154). As a Greek believer, Luke's positive portrayal of the Torah might arguably be considered as a kind of objective and careful apologetic response to all of his readers (cf. Lk 1:1-4), to show why and how a break has occurred between the church and the Ioudaioi.

\section{Acknowledgements}

\section{Competing interests}

The author declares that he has no financial or personal relationships which may have inappropriately influenced him in writing this article.

\section{References}

Barrett, C.K., 1998, A critical and exegetical commentary on the Acts of the Apostles: Introduction and commentary on Acts XV-XXVIII, T\&T Clark, London. (The International Critical Commentary).

Barrett, C.K., 2002, The Acts of the Apostles: A shorter commentary, T\&T Clark, London.

Bauer, W., Danker, F.W., Arndt, W.F. \& Gingrich, F.W. (eds.), 2000, A Greek-English Lexicon of the New Testament and other early Christian Literature (BDAG), University of Chicago Press, Chicago, IL.

Bock, D.L., 2007, Acts, Baker Academic, Grand Rapids, MI, ePub ed. (Baker Exegetical Commentary on the New Testament).

Bruce, F.F., 1990, The Acts of the Apostles: The Greek text with introduction and commentary, Eerdmans, Grand Rapids, MI.

Campbell, W.S., 2008, Paul and the creation of Christian identity, T\&T Clark, London.

Carson, D.A. \& Moo, D.J., 2005, An introduction to the New Testament, Zondervan, Grand Rapids, MI.

Conzelmann, H., 1987, Acts of the Apostles, Fortress, Philadelphia, PA. (Hermeneia).

Cranfield, C.E.B., 1979, The Epistle to the Romans, vol. 2, T\&T Clark, Edinburgh. (The International Critical Commentary).

Dunn, J.D.G., 1988, Romans 9-16, Thomas Nelson, Nashville, TN. (Word Biblical Commentary 38b).

Dunn, J.D.G., 2006, Unity and diversity in the New Testament: An inquiry into the character of earliest Christianity, 3rd edn., SCM, London.

Dunn, J.D.G., 2015, 'Paul within Judaism: Restoring the first-century context to the Apostle. Edited by Mark D. Nanos and Magnus Zetterholm', Journal of Theological Studies 66(2), 782-784. http://dx.doi.org/10.1093/jts/flv088

Du Toit, P.La G., 2013a, Paul and Israel: Flesh, spirit and identity, Ph.D. dissertation, Stellenbosch University, Stellenbosch.

Du Toit, P.La G., 2013b, 'Perspektiewe op die Noagitiese Wette by Paulus, en die Belang daarvan vir Joods-Christelike Dialoog', Litnet Akademies 10(1), 631-656.

Du Toit, P.La G., 2015a, 'Paul's reference to the "Keeping of the Commandments of God" in 1 Corinthians 7:19', Neotestamentica 49(1), 21-45.

Du Toit, P.La G., 2015b, 'The hermeneutical dilemma behind "Anti-Judaism" in the New Testament: An evangelical perspective', Conspectus 20, 43-88.

Eisenbaum, P., 2009, Paul was not a Christian: The original message of a misunderstood Apostle, HarperCollins, New York.

Esler, P.F., 1987, Community and Gospel in Luke-Acts: The social and political motivations of Lucan Theology, Cambridge University Press, Cambridge.

Fee, G.D., 1987, The first epistle to the Corinthians, Eerdmans, Grand Rapids, MI. (The New International Commentary on the New Testament).

Fernando, A., 1998, Acts, Zondervan, Grand Rapids, MI. (The NIV Application Commentary)

Fitzmyer, J.A., 1998, The Acts of the Apostles, Doubleday, New York. (Anchor Bible 31). Franklin, E., 1994, Luke, interpreter of Paul, critic of Matthew, JSOT Press, Sheffield.

Gaertner, D., 1993, Acts, College Press, Joplin, MO. (The College Press NIV Commentary).

Gagnon, R.A.J., 2000, 'Why the "Weak" at Rome cannot be non-Christian Jews', The Catholic Biblical Quarterly 62(1), 64-82.

Haenchen, E., 1966, 'The Book of acts as source material for the history of early Christianity', in L.E. Keck \& J.L. Martyn (eds.), Studies in Luke-Acts: Essays in Honor of Paul Schubert, pp. 258-278, Abingdon Press, Nashville, TN.

Haenchen, E., 1971, The Acts of the Apostles: A commentary, Westminster, Philadelphia, PA.

Horsley, G.H.R., 1981, New documents illustrating early Christianity: A review of the Greek inscriptions and papyri published in 1976, vol. 1, Macquarie University, North Ryde.

Horsley, G.H.R., 1983, New documents illustrating early Christianity: A review of the Greek inscriptions and papyri published in 1978, vol. 3, Macquarie University, North Ryde.

Jervell, J., 1998, Die Apostelgeschicte, Vandenhoeck \& Ruprecht, Göttingen. (Kritischexegetischer Kommentar über das Neue Testament 3).

Johnson, L.T., 1992, The Acts of the Apostles, Liturgical Press, Collegeville, MN. (Sacra Pagina 5).

Keener, C.S., 2012, Acts: An exegetical commentary, vol. 1, Baker Academic, Grand Rapids, MI.

Lentz, J.C., 1993, Luke's portrait of Paul, Cambridge University Press, Cambridge.

Longenecker, R.N., 1981, 'The Acts of the Apostles', in F.E. Gæbelein (ed.), The expositor's Bible commentary, vol. 9, pp. 207-573, Zondervan, Grand Rapids, MI.

Longenecker, R.N., 2015, Paul: Apostle of liberty, Eerdmans, Grand Rapids, MI.

Marguerat, D., 2004, The first Christian historian: Writing the 'Acts of the Apostles', Cambridge University Press, Cambridge.

Marshall, I.H., 1980, Acts, Inter-Varsity, Leicester. (Tyndale New Testament Commentaries).

Moo, D.J., 1996, The Epistle to the Romans, Eerdmans, Grand Rapids, MI. (The New International Commentary of the New Testament). 
Moo. D.J., 2013, Galatians, Baker Academic, Grand Rapids, MI. (Baker Exegetical Commentary on the New Testament).

Mount, C., 2002, Pauline Christianity: Luke-Acts and the Legacy of Paul, Brill, Leiden.

Nanos, M.D., 1996, The mystery of Romans: The Jewish context of Paul's letter Fortress, Minneapolis, MN.

Nanos, M.D., 2009, 'The myth of the "Law-Free" Paul standing between Christians and Jews', Studies in Christian-Jewish Relations 4, 1-21.

Nanos, M.D., 2012, 'Paul's relationship to Torah in Light of his Strategy "to Become Everything to Everyone" (1 Corinthians 9.19-23)', in R. Bieringer \& D. Pollefeyt
(eds.), Paul and Judaism: Crosscurrents in Pauline Exegesis and the Study of (eds.), Paul and Judaism: Crosscurrents in Pauline Exegesis
Jewish-Christian Relations, pp. 106-140, T\&T Clark, London.

Parsons, M.C., 2008, Acts, Baker Academic, Grand Rapids, MI. (Paideia Commentaries on the New Testament).

Pervo, R.I., 2009, Acts, Fortress, Minneapolis, MN. (Hermeneia).

Peterson, D.G., 2009, The Acts of the Apostles, Eerdmans, Grand Rapids, MI. (The Pillar New Testament Commentary).

Polhill, J.B., 1992, Acts, Broadman, Nashville, TN, ePub ed. (New American Commentary 26).

Porter, S.E., [1999] 2008, Paul in Acts, Hendrickson Publishers, Peabody, MA

Ramsay, W.M., 1925, St. Paul the traveller and the Roman citizen, Hodder and Stoughton, London.

Sailhamer, J.H., 1992, The Pentateuch as narrative: A biblical-theological commentary, Zondervan, Grand Rapids, MI.

Sanders, E.P., 1983, Paul, the law and the Jewish people, Fortress Press, Philadelphia, PA. Schnabel, E.J., 2012, Acts, Zondervan, Grand Rapids, MI. (Zondervan Exegetical Commentary on the New Testament).
Schreiner, T.R., [1998] 2013, Romans, Baker Academic, Grand Rapids, MI, ePub ed. (Baker Exegetical Commentary on the New Testament).

Schreiner, T.R., 2010, Galatians, Zondervan, Grand Rapids, MI, Kindle ed. (Zondervan Exegetical Commentary on the New Testament).

Schüssler-Fiorenza, E., 1976, Aspects of religious propaganda in Judaism and early Christianity, University of Notre Dame Press, London.

Sechrest, L.L., 2009, A former Jew: Paul and the dialectics of race, T\&T Clark, London. Stott, J.R.W., 1990, The spirit, the church, and the world: The message of acts, Inter-Varsity, Downers Grove, IL. (The Bible Speaks Today).

Talbert, C.H., 2005, Reading acts: A literary and theological commentary on the Acts of the Apostles, Smyth \& Helwys, Macon, GA.

Thiselton, A.C., 2000, The First Epistle to the Corinthians, Eerdmans, Grand Rapids, MI. (The New International Greek Testament Commentary).

Tomson, P.J., 1990, Paul and the Jewish Law: Halakha in the Letters of the Apostle to the Gentiles, Van Gorcum, Assen.

Tucker, J.B., 2011, Remain in your Calling: Paul and the continuation of social identities in 1 Corinthians, Pickwick, Eugene, OR.

Wall, R.W., 2002, 'The Acts of the Apostles', in L.E. Keck (ed.), The New Interpreter's Bible, pp. 1-368, Abingdon Press, Nashville, TN.

Wallace, D.B., 1996, Greek grammar beyond the basics: An exegetical syntax of the New Testament, Zondervan, Grand Rapids, Ml.

Witherington, B. III, 1998, The Acts of the Apostles: A socio-rhetorical commentary, Eerdmans, Grand Rapids, MI.

Woods, D., 2015, 'Does Acts 15:9 refute intra-ecclesial Jew-Gentile distinction?', Conspectus 19, 105-145.

Wright, N.T., 2013, Paul and the faithfulness of God, 2 vols., SPCK, London. 